4

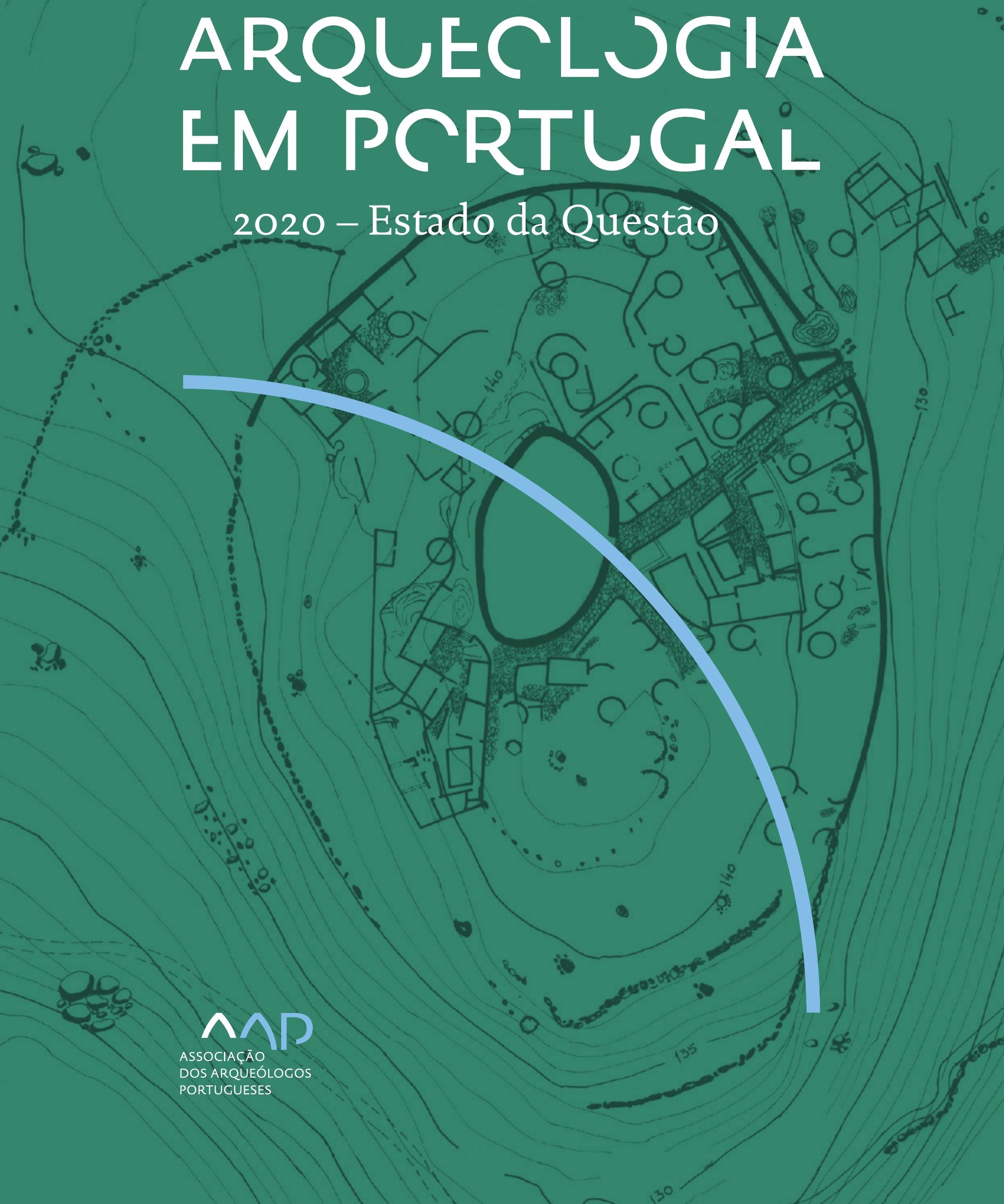


Coordenação editorial: José Morais Arnaud, César Neves e Andrea Martins Design gráfico: Flatland Design

AAP - ISBN: 978-972-9451-89-8

CITCEM - ISBN: 978-989-8970-25-1

Associação dos Arqueólogos Portugueses e CITCEM

Lisboa, 2020

O conteúdo dos artigos é da inteira responsabilidade dos autores. Sendo assim a Associação dos Arqueólogos Portugueses declina qualquer responsabilidade por eventuais equívocos ou questões de ordem ética e legal.

Desenho de capa:

Planta do castro de Monte Mozinho (Museu Municipal de Penafiel).

\section{$\hat{\wedge} \mathrm{P}$}

DOS ARQUEÓLOGOS PORTUGUESES

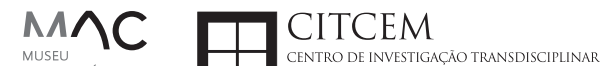
MUSEU
ARQUELLÓGICO
DO CARMO
U.PORTO

FLUP FACULDADE DE LETRAS
UNIVERSIDADE DO PORTO

Apoio

EC para a Ciência 


\section{Índice}

15 Prefácio

José Morais Arnaud

\section{Historiografia e Teoria}

17 Território, comunidade, memória e emoção: a contribuição da história da arqueologia (algumas primeiras e breves reflexões)

Ana Cristina Martins

25 Como descolonizar a arqueologia portuguesa?

Rui Gomes Coelho

41 Arqueologia e Modernidade: uma revisitação pessoal e breve de alguns aspetos da obra homónima de Julian Thomas de 2004

Vítor Oliveira Jorge

57 Dados para a História das Mulheres na Arqueologia portuguesa, dos finais do século XIX aos inícios do século XX: números, nomes e tabelas

Filipa Dimas / Mariana Diniz

73 Retractos da arqueologia portuguesa na imprensa: (in)visibilidades no feminino

Catarina Costeira / Elsa Luís

85 Arqueologia e Arqueólogos no Norte de Portugal Jacinta Bugalhão

101 Vieira Guimarães (1864-1939) e a arqueologia em Tomar: uma abordagem sobre o território e as gentes

João Amendoeira Peixoto / Ana Cristina Martins

115 Os memoráveis? A arqueologia algarvia na imprensa nacional e regional na presente centúria (2001-2019): características, visões do(s) passado(s) e a arqueologia

enquanto marca

Frederico Agosto / João Silva

129 A Evolução da Arqueologia Urbana e a Valorização Patrimonial no Barlavento Algarvio: Os casos de Portimão e Silves

Artur Mateus / Diogo Varandas / Rafael Boavida

\section{Gestão, Valorização e Salvaguarda do Património}

145 O Caderno Reivindicativo e as condições de trabalho em Arqueologia Miguel Rocha / Liliana Matias Carvalho / Regis Barbosa / Mauro Correia / Sara Simões / Jacinta Bugalhão / Sara Brito / Liliana Veríssimo Carvalho / Richard Peace / Pedro Peça / Cézer Santos

155 Os Estudos de Impacte Patrimonial como elemento para uma estratégia sustentável de minimização de impactes no âmbito de reconversões agrícolas Tiago do Pereiro

165 Salvaguarda de Património arqueológico em operações florestais: gestão e sensibilização Filipa Bragança / Gertrudes Zambujo / Sandra Lourenço / Belém Paiva / Carlos Banha / Frederico Tatá Regala / Helena Moura / Jacinta Bugalhão / João Marques / José Correia / Pedro Faria / Samuel Melro

179 Os valores do Património: uma investigação sobre os Sítios Pré-históricos de Arte Rupestre do Vale do Rio Côa e de Siega Verde José Paulo Francisco 
189 Conjugando recursos arqueológicos e naturais para potenciar as visitas ao Geoparque Litoral de Viana do Castelo (Noroeste de Portugal)

Hugo A. Sampaio / Ana M.S. Bettencourt / Susana Marinho / Ricardo Carvalhido

203 Áreas de Potencial Arqueológico na Região do Médio Tejo: Modelo Espacial Preditivo Rita Ferreira Anastácio / Ana Filipa Martins / Luiz Oosterbeek

223 Património Arqueológico e Gestão Territorial: O contributo da Arqueologia para a revisão do PDM de Avis

Ana Cristina Ribeiro

237 A coleção arqueológica do extinto Museu Municipal do Porto - Origens, Percursos e Estudos

Sónia Couto

251 Valpaços - uma nova carta arqueológica

Pedro Pereira / Maria de Fátima Casares Machado

263 Arqueologia na Cidade de Peniche

Adriano Constantino / Luís Rendeiro

273 Arqueologia Urbana: a cidade de Lagos como caso de Estudo Cátia Neto

285 Estratégias de promoção do património cultural subaquático nos Açores. O caso da ilha do Faial

José Luís Neto / José Bettencourt / Luís Borges / Pedro Parreira

297 Carta Arqueológica da Cidade Velha: Uma primeira abordagem

Jaylson Monteiro / Nireide Tavares / Sara da Veiga / Claudino Ramos / Edson Brito /

Carlos Carvalho / Francisco Moreira / Adalberto Tavares

311 Antropologia Virtual: novas metodologias para a análise morfológica e funcional Ricardo Miguel Godinho / Célia Gonçalves

\section{Didáctica da Arqueologia}

327 Como os projetos de Arqueologia podem contribuir para uma comunidade culturalmente mais consciente Alexandra Figueiredo / Claúdio Monteiro / Adolfo Silveira / Ricardo Lopes

337 Educação Patrimonial - Um cidadão esclarecido é um cidadão ativo! Ana Paula Almeida

351 A aproximação da Arqueologia à sala de aula: um caso de estudo no $3^{\circ}$ ciclo do Ensino Básico Luís Serrão Gil

363 Arqueologia 3.o - Pensar e comunicar a Arqueologia para um futuro sustentável Mónica Rolo

377 “Conversa de Arqueólogos" - Divulgar a Arqueologia em tempos de Pandemia Diogo Teixeira Dias

389 Escola Profissional de Arqueologia: desafios e oportunidades Susana Nunes / Dulcineia Pinto / Júlia Silva / Ana Mascarenhas

399 Os Museus de Arqueologia e os Jovens: a oferta educativa para o público adolescente Beatriz Correia Barata / Leonor Medeiros

411 O museu universitário como mediador entre a ciência e a sociedade: o exemplo da secção de arqueologia no Museu de História Natural e da Ciência da Universidade do Porto (MHNC-UP)

Rita Gaspar 
421 Museu de Lanifícios: Real Fábrica de Panos. Atividades no âmbito da Arqueologia Beatriz Correia Barata / Rita Salvado

427 Arqueologia Pública e o caso da localidade da Mata (Torres Novas) Cláudia Manso / Ana Rita Ferreira / Cristiana Ferreira / Vanessa Cardoso Antunes

431 Do sítio arqueológico ao museu: um percurso (também) didático Lídia Fernandes

447 Estão todos convidados para a Festa! E para dançar também... O projecto do Serviço Educativo do Museu Arqueológico do Carmo na $5^{\underline{a}}$ Edição da Festa da Arqueologia Rita Pires dos Santos

459 O “Clã de Carenque”, um projeto didático de arqueologia Eduardo Gonzalez Rocha

469 Mediação cultural: peixe que puxa carroça nas Ruínas Romanas de Troia Inês Vaz Pinto / Ana Patrícia Magalhães / Patrícia Brum / Filipa Santos

481 Didática Arqueológica, experiências do Projeto Mértola Vila Museu Maria de Fátima Palma / Clara Rodrigues / Susana Gómez / Lígia Rafael

\section{Arte Rupestre}

497 Os inventários de arte rupestre em Portugal Mila Simões de Abreu

513 O projeto FIRST-ART - conservação, documentação e gestão das primeiras manifestações de arte rupestre no Sudoeste da Península Ibérica: as grutas do Escoural e Maltravieso Sara Garcês / Hipólito Collado / José Julio García Arranz / Luiz Oosterbeek / António Carlos Silva / Pierluigi Rosina / Hugo Gomes / Anabela Borralheiro Pereira / George Nash / Esmeralda Gomes / Nelson Almeida / Carlos Carpetudo

523 Trabalhos de documentação de arte paleolítica realizados no âmbito do projeto PalæoCôa André Tomás Santos / António Fernando Barbosa / Luís Luís / Marcelo Silvestre / Thierry Aubry

537 Imagens fantasmagóricas, silhuetas elusivas: as figuras humanas na arte do Paleolítico Superior da região do Côa Mário Reis

$55^{1}$ Os motivos zoomórficos representados nas placas de tear de Vila Nova de São Pedro (Azambuja, Portugal) Andrea Martins / César Neves / José M. Arnaud / Mariana Diniz

571 Arte Rupestre do Monte de Góios (Lanhelas, Caminha). Síntese dos resultados dos trabalhos efectuados em 2007-2009 Mário Varela Gomes

599 Gravuras rupestres de barquiformes no Monte de S. Romão, Guimarães, Noroeste de Portugal Daniela Cardoso

613 Círculos segmentados gravados na Bacia do Rio Lima (Noroeste de Portugal): contributos para o seu estudo Diogo Marinho / Ana M.S. Bettencourt / Hugo Aluai Sampaio

631 Equídeos gravados no curso inferior do Rio Mouro, Monção (NW Portugal). Análise preliminar Coutinho, L.M. / Bettencourt, A.M.S / Sampaio, Hugo A.S

645 Paletas na Arte Rupestre do Noroeste de Portugal. Inventário preliminar Bruna Sousa Afonso / Ana M. S. Bettencourt / Hugo A. Sampaio 


\section{Pré-História}

661 O projeto Miño/Minho: balanço de quatro anos de trabalhos arqueológicos Sérgio Monteiro-Rodrigues / João Pedro Cunha-Ribeiro / Eduardo Méndez-Quintas / Carlos Ferreira / Pedro Xavier / José Meireles / Alberto Gomes / Manuel Santonja / Alfredo Pérez-González

677 A ocupação paleolítica da margem esquerda do Baixo Minho: a indústria lítica do sítio de Pedreiras 2 (Monção, Portugal) e a sua integração no contexto regional Carlos Ferreira / João Pedro Cunha-Ribeiro / Sérgio Monteiro-Rodrigues / Eduardo Méndez-Quintas / Pedro Xavier / José Meireles / Alberto Gomes / Manuel Santonja / Alfredo Pérez-González

693 O sítio acheulense do Plistocénico médio da Gruta da Aroeira Joan Daura / Montserrat Sanz / Filipa Rodrigues / Pedro Souto / João Zilhão

703 As sociedades neandertais no Barlavento algarvio: modelos preditivos com recurso aos SIG

Daniela Maio

715 A utilização de quartzo durante o Paleolítico Superior no território dos vales dos rios Vouga e Côa

Cristina Gameiro / Thierry Aubry / Bárbara Costa / Sérgio Gomes / Luís Luís / Carmen Manzano / André Tomás Santos

733 Uma perspetiva diacrónica da ocupação do concheiro do Cabeço da Amoreira (Muge, Portugal) a partir da tecnologia lítica Joana Belmiro / João Cascalheira / Célia Gonçalves

745 Novos dados sobre a Pré-história Antiga no concelho de Palmela. A intervenção arqueológica no sítio do Poceirão I

Michelle Teixeira Santos

757 Problemas em torno de Datas Absolutas Pré-Históricas no Norte do Alentejo Jorge de Oliveira

771 Povoamento pré-histórico nas áreas montanhosas do NO de Portugal: o Abrigo 1 de Vale de Cerdeira Pedro Xavier / José Meireles / Carlos Alves

783 Apreciação do povoamento do Neolítico Inicial na Baixa Bacia do Douro. A Lavra I (Serra da Aboboreira) como caso de estudo Maria de Jesus Sanches

797 O Processo de Neolitização na Plataforma do Mondego: os dados do Sector C do Outeiro dos Castelos de Beijós (Carregal do Sal)

João Carlos de Senna-Martinez / José Manuel Quintã Ventura / Andreia Carvalho / Cíntia Maurício

823 Novos trabalhos na Lapa da Bugalheira (Almonda, Torres Novas) Filipa Rodrigues / Pedro Souto / Artur Ferreira / Alexandre Varanda / Luís Gomes / Helena Gomes / João Zilhão

837 A pedra polida e afeiçoada do sítio do Neolítico médio da Moita do Ourives (Benavente, Portugal)

César Neves

857 Casal do Outeiro (Encarnação, Mafra): novos contributos para o conhecimento do povoamento do Neolítico final na Península de Lisboa.

Cátia Delicado / Carlos Maneira e Costa / Marta Miranda / Ana Catarina Sousa

873 Stresse infantil, morbilidade e mortalidade no sítio arqueológico do Neolítico Final/ Calcolítico ( $4^{\circ}$ e $3^{\circ}$ milénio a.C.) do Monte do Carrascal 2 (Ferreira do Alentejo, Beja) Liliana Matias de Carvalho / Sofia N. Wasterlain 
885 Come together: O Conjunto Megalítico das Motas (Monção, Viana do Castelo) e as expressões Campaniformes do Alto Minho Ana Catarina Basílio / Rui Ramos

899 Trabalhos arqueológicos no sítio Calcolítico da Pedreira do Poio Carla Magalhães / João Muralha / Mário Reis / António Batarda Fernandes

913 O sítio arqueológico de Castanheiro do Vento. Da arquitectura do sítio à arquitectura de um território João Muralha Cardoso

925 Estudo zooarqueológico das faunas do Calcolítico final de Vila Nova de São Pedro (Azambuja, Portugal): Campanhas de 2017 e 2018 Cleia Detry / Ana Catarina Francisco / Mariana Diniz / Andrea Martins / César Neves / José Morais Arnaud

943 As faunas depositadas no Museu Arqueológico do Carmo provenientes de Vila Nova de São Pedro (Azambuja): as campanhas de 1937 a 1967 Ana Catarina Francisco / Cleia Detry / César Neves / Andrea Martins / Mariana Diniz / José Morais Arnaud

959 Análise funcional de material lítico em sílex do castro de Vila Nova de S. Pedro (Azambuja, Portugal): uma primeira abordagem Rafael Lima

971 O recinto da Folha do Ouro 1 (Serpa) no contexto dos recintos de fossos calcolíticos alentejanos

António Carlos Valera / Tiago do Pereiro / Pedro Valério / António M. Monge Soares

\section{Proto-História}

987 Produção de sal marinho na Idade do Bronze do noroeste Português. Alguns dados para uma reflexão

Ana M. S. Bettencourt / Sara Luz / Nuno Oliveira / Pedro P. Simões / Maria Isabel C. Alves / Emílio Abad-Vidal

1001 A estátua-menir do Pedrão ou de São Bartolomeu do Mar (Esposende, noroeste de Portugal) no contexto arqueológico da fachada costeira de entre os rios Neiva e Cávado Ana M. S. Bettencourt / Manuel Santos-Estévez / Pedro Pimenta Simões / Luís Gonçalves

1015 O Castro do Muro (Vandoma/Baltar, Paredes) - notas para uma biografia de ocupação da Idade do Bronze à Idade Média

Maria Antónia D. Silva / Ana M. S. Bettencourt / António Manuel S. P. Silva / Natália Félix

1031 Do Bronze Final à Idade Média - continuidades e hiatos na ocupação de Povoados em Oliveira de Azeméis João Tiago Tavares / Adriaan de Man

1041 As faunas do final da Idade do Bronze no Sul de Portugal: leituras desde o Outeiro do Circo (Beja)

Nelson J. Almeida / Íris Dias / Cleia Detry / Eduardo Porfírio / Miguel Serra

1055 A Espada do Monte das Oliveiras (Serpa) - uma arma do Bronze Pleno do Sudoeste Rui M. G. Monge Soares / Pedro Valério / Mariana Nabais / António M. Monge Soares

1065 São Julião da Branca (Albergaria-a-Velha) - Investigação e valorização de um povoado do Bronze Final

António Manuel S. P. Silva / Paulo A. P. Lemos / Sara Almeida e Silva / Edite Martins de Sá

1083 Do castro de S. João ao Mosteiro de Santa Clara: notícia de uma intervenção arqueológica, em Vila do Conde Rui Pinheiro 
1095 O castro de Ovil (Espinho), um quarto de século de investigação - resultados e questões em aberto

Jorge Fernando Salvador / António Manuel S. P. Silva

1111 O Castro de Salreu (Estarreja), um povoado proto-histórico no litoral do Entre Douro e Vouga

Sara Almeida e Silva / António Manuel S. P. Silva / Paulo A. P. Lemos / Edite Martins de Sá

1127 Castro de Nossa Senhora das Necessidades (Sernancelhe): uma primeira análise artefactual Telma Susana O. Ribeiro

${ }_{1141}$ A cividade de Bagunte. O estado atual da investigação Pedro Brochado de Almeida

1153 Zoomorfos na cerâmica da Idade do Ferro no NW Peninsular: inventário, cronologias e significado Nuno Oliveira / Cristina Seoane

1163 Vasos gregos em Portugal: diferentes maneiras de contar a história do intercâmbio cultural na Idade do Ferro

Daniela Ferreira

1175 Os exotica da necrópole da Idade do Ferro do Olival do Senhor dos Mártires (Alcácer do Sal) no seu contexto regional

Francisco B. Gomes

\section{Antiguidade Clássica e Tardia}

1191 O uso de madeira como combustível no sítio da Quinta de Crestelos (Baixo Sabor): da Idade do Ferro à Romanização Filipe Vaz / João Tereso / Sérgio Simões Pereira / José Sastre / Javier Larrazabal Galarza / Susana Cosme / José António Pereira / Israel Espi

1207 Cultivos de Época Romana no Baixo Sabor: continuidade em tempos de mudança? João Pedro Tereso / Sérgio Simões Pereira / Filipe Santos / Luís Seabra / Filipe Vaz

1221 A casa romana na Hispânia: aplicação dos modelos itálicos nas províncias ibéricas Fernanda Magalhães / Diego Machado / Manuela Martins

1235 As pinturas murais romanas da Rua General Sousa Machado, n. ${ }^{5}$ 1, Chaves José Carvalho

1243 Trás do Castelo (Vale de Mir, Pegarinhos, Alijó) - Uma exploração agrícola romana do Douro

Tony Silvino / Pedro Pereira

1255 A sequência de ocupação no quadrante sudeste de Bracara Augusta: as transformações de uma unidade doméstica Lara Fernandes / Manuela Martins

1263 Os Mosaicos com decoração geométrica e geométrico-vegetalista dos sítios arqueológicos da área do Conuentus Bracaraugustanus. Novas abordagens quanto à conservação, restauro, decoração e datação Maria de Fátima Abraços / Licínia Wrench

1277 “Casa Romana” do Castro de São Domingos (Cristelos, Lousada): Escavação, Estudo e Musealização Paulo André de P. Lemos

1291 A arqueobotânica no Castro de Guifões (Matosinhos, Noroeste de Portugal): O primeiro estudo carpológico

Luís Seabra / Andreia Arezes / Catarina Magalhães / José Varela / João Pedro Tereso 
1305 Um Horreum Augustano na Foz do Douro (Monte do Castelo de Gaia, Vila Nova de Gaia) Rui Ramos

1311 Ponderais romanos na Lusitânia: padrões, formas, materiais e contextos de utilização Diego Barrios Rodríguez

1323 Um almofariz centro-itálico na foz do Mondego

Marco Penajoia

1335 Estruturas romanas de Carnide - Lisboa Luísa Batalha / Mário Monteiro / Guilherme Cardoso

1347 O contexto funerário do sector da "necrópole NO" da Rua das Portas de S. Antão (Lisboa): o espaço, os artefactos, os indivíduos e a sua interconectividade na interpretação do passado Sílvia Loja, José Carlos Quaresma, Nelson Cabaço, Marina Lourenço, Sílvia Casimiro, Rodrigo Banha da Silva, Francisca Alves-Cardoso

${ }_{1361}$ Povoamento em época Romana na Amadora - resultados de um projeto pluridisciplinar Gisela Encarnação / Vanessa Dias

1371 A Arquitectura Residencial em Mirobriga (Santiago do Cacém): contributo a partir de um estudo de caso Filipe Sousa / Catarina Felício

${ }_{1385}$ O fim do ciclo. Saneamento e gestão de resíduos nos edifícios termais de Mirobriga (Santiago do Cacém)

Catarina Felício / Filipe Sousa

1399 Balsa, Topografia e Urbanismo de uma Cidade Portuária Vítor Silva Dias / João Pedro Bernardes / Celso Candeias / Cristina Tété Garcia

1413 No Largo das Mouras Velhas em Faro (2017): novas evidências da necrópole norte de Ossonoba e da sua ocupação medieval Ricardo Costeira da Silva / Paulo Botelho / Fernando Santos / Liliana Nunes

1429 Instrumentos de pesca recuperados numa fábrica de salga em Ossonoba (Faro) Inês Rasteiro / Ricardo Costeira da Silva / Paulo Botelho

1439 A Necrópole Romana do Eirô, Duas Igrejas (Penafiel): intervenção arqueológica de 2016 Laura Sousa / Teresa Soeiro

1457 Ritual, descarte ou afetividade? A presença de Canis lupus familiaris na Necrópole Noroeste de Olisipo (Lisboa)

Beatriz Calapez Santos / Sofia Simões Pereira / Rodrigo Banha da Silva / Sílvia Casimiro / Cleia Detry / Francisca Alves Cardoso

1467 Dinâmicas económicas em Bracara na Antiguidade Tardia Diego Machado / Manuela Martins / Fernanda Magalhães / Natália Botica

1479 Cerâmicas e Vidros da Antiguidade Tardia do Edifício sob a Igreja do Bom Jesus (Vila Nova de Gaia) Joaquim Filipe Ramos

1493 Novos contributos para a topografia histórica de Mértola no período romano e na Antiguidade Tardia Virgílio Lopes

\section{8. Época Medieval}

1511 Cerâmicas islâmicas no Garb setentrional "português": algumas evidências e incógnitas Constança dos Santos / Helena Catarino / Susana Gómez / Maria José Gonçalves / Isabel Inácio / Gonçalo Lopes / Jacinta Bugalhão / Sandra Cavaco / Jaquelina Covaneiro / Isabel Cristina Fernandes / Ana Sofia Gomes 
1525 Contributo para o conhecimento da cosmética islâmica, em Silves, durante a Idade Média Rosa Varela Gomes

1537 Yábura e o seu território - uma análise histórico-arqueológica de Évora entre os séculos VIII-XII José Rui Santos

1547 A encosta sul do Castelo de Palmela - resultados preliminares da escavação arqueológica Luís Filipe Pereira / Michelle Teixeira Santos

1559 A igreja de São Lourenço (Mouraria, Lisboa): um conjunto de silos e de cerâmica medieval islâmica

Andreia Filipa Moreira Rodrigues

1571 O registo material de movimentações populacionais no Médio Tejo, durante os séculos XII-XIII. Dois casos de "sunken featured buildings", nos concelhos de Cartaxo e Torres Novas Marco Liberato / Helena Santos / Nuno Santos

1585 O nordeste transmontano nos alvores da Idade média. Notas para reflexão Ana Maria da Costa Oliveira

1601 Sepulturas escavadas na rocha do Norte de Portugal e do Vale do Douro: primeiros resultados do Projecto SER-NPVD

Mário Jorge Barroca / César Guedes / Andreia Arezes / Ana Maria Oliveira

1619 "Portucalem Castrum Novum" entre o Mediterrâneo e o Atlântico: o estudo dos materiais cerâmicos alto-medievais do arqueossítio da rua de D. Hugo, nํ. 5 (Porto) João Luís Veloso

1627 A Alta Idade Média na fronteira de Lafões: notas preliminares sobre a Arqueologia no Concelho de Vouzela

Manuel Luís Real / Catarina Tente

1641 Um conjunto cerâmico medieval fora de portas: um breve testemunho aveirense Susana Temudo

${ }_{1651}$ Os Lóios do Porto: uma perspetiva integrada no panorama funerário da Baixa Idade Média à Época Moderna em meios urbanos em Portugal

Ana Lema Seabra

1659 O Caminho Português Interior de Santiago como eixo viário na Idade Média Pedro Azevedo

1665 Morfologia Urbana: Um exercício em torno do Castelo de Ourém André Donas-Botto / Jaqueline Pereira

1677 Intervenção arqueológica na Rua Marquês de Pombal/Largo do Espírito Santo (Bucelas, Loures)

Florbela Estêvão / Nathalie Antunes-Ferreira / Dário Ramos Neves / Inês Lisboa

1691 O Cemitério Medieval do Poço do Borratém e a espacialidade funerária na cidade de Lisboa Inês Belém / Vanessa Filipe / Vasco Noronha Vieira / Sónia Ferro / Rodrigo Banha da Silva

1705 Um Espaço Funerário Conventual do séc. XV em Lisboa: o caso do Convento de São Domingos da Cidade Sérgio Pedroso / Sílvia Casimiro / Rodrigo Banha da Silva / Francisca Alves Cardoso

\section{9. Época Moderna e Contemporânea}

1721 Arqueologia Moderna em Portugal: algumas reflexões críticas em torno da quantificação de conjuntos cerâmicos e suas inferências históricas e antropológicas Rodrigo Banha da Silva / André Bargão / Sara da Cruz Ferreira

1733 Faianças de dois contextos entre os finais do século XVI e XVIII do Palácio dos Condes de Penafiel, Lisboa

Martim Lopes / Tomás Mesquita 
1747 Um perfil de consumo do século XVIII na foz do Tejo: O caso do Mercado da Ribeira, Lisboa Sara da Cruz Ferreira / Rodrigo Banha da Silva / André Bargão

1761 Os Cachimbos dos Séculos XVII e XVIII do Palácio Mesquitela e Convento dos Inglesinhos (Lisboa)

Inês Simão / Marina Pinto / João Pimenta / Sara da Cruz Ferreira / André Bargão / Rodrigo Banha da Silva

1775 "Tomar os fumos da erua que chamão em Portugal erua sancta». Estudo de Cachimbos provenientes da Rua do Terreiro do Trigo, Lisboa

Miguel Martins de Sousa / José Pedro Henriques / Vanessa Galiza Filipe

1787 Cachimbos de Barro Caulínitico da Sé da Cidade Velha (República de Cabo Verde)

Rodrigo Banha da Silva / João Pimenta / Clementino Amaro

1801 Algumas considerações sobre espólio não cerâmico recuperado no Largo de Jesus (Lisboa) Carlos Boavida

1815 Adereços de vidro, dos séculos XVI-XVIII, procedentes do antigo Convento de Santana de Lisboa (anéis, braceletes e contas)

Joana Gonçalves / Rosa Varela Gomes / Mário Varela Gomes

1837 Da ostentação, luxo e poder à simplicidade do uso quotidiano: arqueologia e simbologia de joias e adornos da Idade Moderna Portuguesa Jéssica Iglésias

1849 Os amuletos em Portugal - dos objetos às superstições: o coral vermelho Alexandra Vieira

1865 Cerâmicas de Vila Franca de Xira nos séculos XV e XVI Eva Pires

1879 «Não passa por teu o que me pertence». Marcas de individualização associadas a faianças do Convento de Nossa Senhora de Aracoeli, Alcácer do Sal Catarina Parreira / Íris Fragoso / Miguel Martins de Sousa

1891 Cerâmica de Leiria: alguns focos de produção

Jaqueline Pereira / André Donas-Botto

1901 Os Fornos na Rua da Biquinha, em Óbidos Hugo Silva / Filipe Oliveira

1909 A casa de Pêro Fernandes, contador dos contos de D. Manuel I: o sítio arqueológico da Silha do Alferes, Seixal (século XVI) Mariana Nunes Ferreira

1921 O Alto da Vigia (Sintra) e a vigilância e defesa da costa Alexandre Gonçalves / Sandra Santos

1937 O contexto da torre sineira da Igreja de Santa Maria de Loures Paulo Calaveira / Martim Lopes

1949 A Necrópole do Hospital Militar do Castelo de São Jorge e as práticas funerárias na Lisboa de Época Moderna Susana Henriques / Liliana Matias de Carvalho / Ana Amarante / Sofia N. Wasterlain

1963 SAND - Sarilhos Grandes Entre dois Mundos: o adro da Igreja e a Paleobiologia dos ossos humanos recuperados

Paula Alves Pereira / Roger Lee Jesus / Bruno M. Magalhães

1975 Expansão urbana da vila de Cascais no século XVII e XVIII: a intervenção arqueológica na Rua da Vitória no 15 a 17

Tiago Pereira / Vanessa Filipe

1987 Novos dados para o conhecimento do Urbanismo de Faro em época Moderna Ana Rosa 
1995 Um exemplo de Arqueologia Urbana em Alcoutim: o Antigo Edifício dos CTT Marco Fernandes / Marta Dias / Alexandra Gradim / Virgílio Lopes / Susana Gómez Martínez

2007 Palácio dos Ferrazes (Rua das Flores/Rua da Vitória, Porto): a cocheira de Domingos Oliveira Maia

Francisco Raimundo

2021 As muitas vidas de um edifício urbano: História, Arqueologia e Antropologia no antigo Recreatório Paroquial de Penafiel Helena Bernardo / Jorge Sampaio / Marta Borges

2035 O convento de Nossa Senhora da Esperança de Ponta Delgada: o contributo da arqueologia para o conhecimento de um monumento identitário João Gonçalves Araújo / N’Zinga Oliveira

2047 Arqueologia na ilha do Corvo... em busca da capela de Nossa Senhora do Rosário Tânia Manuel Casimiro / José Luís Neto / Luís Borges / Pedro Parreira

2059 Perdidos à vista da Costa. Trabalhos arqueológicos subaquáticos na Barra do Tejo Jorge Freire / José Bettencourt / Augusto Salgado

2071 Arqueologia marítima em Cabo Verde: enquadramento e primeiros resultados do projecto CONCHA

José Bettencourt / Adilson Dias / Carlos Lima / Christelle Chouzenoux / Cristóvão Fonseca / Dúnia Pereira / Gonçalo Lopes / Inês Coelho / Jaylson Monteiro / José Lima / Maria Eugénia Alves / Patrícia Carvalho / Tiago Silva

2085 Trabalhos arqueológicos na Cidade Velha (Ribeira Grande de Santiago, Cabo Verde): reflexões sobre um projecto de investigação e divulgação patrimonial André Teixeira / Jaylson Monteiro / Mariana Mateus / Nireide Tavares / Cristovão Fonseca / Gonçalo C. Lopes / Joana Bento Torres / Dúnia Pereira / André Bargão / Aurélie Mayer / Bruno Zélie / Carlos Lima / Christelle Chouzenoux / Inês Henriques / Inês Pinto Coelho / José Lima / Patrícia Carvalho / Tiago Silva

2103 A antiga fortificação de Quelba / Khor Kalba (E.A.U.). Resultados de quatro campanhas de escavações, problemáticas e perspectivas futuras Rui Carita / Rosa Varela Gomes / Mário Varela Gomes / Kamyar Kamyad

2123 Colónias para homens novos: arqueologia da colonização agrária fascista no noroeste ibérico Xurxo Ayán Vila / José Mạ . Señorán Martín 


\title{
A ESPADA DO MONTE DAS OLIVEIRAS (SERPA) - UMA ARMA DO BRONZE PLENO DO SUDOESTE
}

\author{
Rui M.G. Monge Soares ${ }^{1}$, Pedro Valério ${ }^{2}$, Mariana Nabais ${ }^{1}, 3$, António M. Monge Soares ${ }^{2}$
}

\begin{abstract}
RESUMO
Nesta comunicação dá-se a conhecer uma espada, atribuível ao Bronze Pleno do Sudoeste, encontrada há vários anos em trabalhos agrícolas próximo da cidade de Serpa. A espada foi encontrada aparentemente descontextualizada, posteriormente limpa de produtos de corrosão e guardada pelo achador que, amavelmente, nos permitiu o seu estudo. A espada teria cerca de $50 \mathrm{~cm}$ de comprimento e o seu encabamento era efectuado por três rebites alojados em entalhes, dos quais se conservam dois. As cabeças destes têm a forma de calotes esféricas, encontrando-se cobertas por uma folha de ouro. A composição elementar do metal da lâmina da espada, bem como da folha de ouro que recobre as cabeças dos rebites, foi quantificada fazendo uso de um equipamento portátil de espectrometria de fluorescência de raios X. Foi assim possível determinar que a lâmina foi manufacturada com cobre arsenical, enquanto que a composição da folha de ouro indicia que a mesma corresponde a uma liga natural. Faz-se, por fim, uma comparação da espada do Monte das Oliveiras com os poucos exemplares deste tipo de arma conhecidos no sul ibérico, tomando também em consideração o tipo de encabamento que parece, até agora, uma variante única em espadas e que é relativamente raro em armas de forma similar, designadamente em punhais.

Palavras-chave: Encabamento com duplo arco em ferradura, Entalhes para rebitagem, Cobre arsenical, Liga de ouro natural.
\end{abstract}

\section{ABSTRACT}

In this paper, we present a detailed examination of a sword dating from the Southwestern Middle Bronze Age, which was found several years ago during farming activities near the town of Serpa, Portugal. The sword was apparently found out of an archaeological context. The finder of the sword, who kindly allowed us to study it, cleaned the artefact of its corrosion and kept it in good conditions. The sword is about $50 \mathrm{~cm}$ long and its handle show two rivets (another one is missing) which are kept housed in notches. The rivets' heads are spherical caps covered with a golden leaf. The use of a p-EDXRF equipment allowed us to determine and quantify the elemental composition of the blade, as well as of the golden leaf covering the rivet heads. It was thus possible to establish that the blade was manufactured with arsenical copper, while the composition of the golden leaf refers to a natural alloy. Finally, the Monte das Oliveiras sword is compared with several other coeval examples of Southern Iberia weaponry. Its hilt design, namely the three peripheral notches, seems to be of an unique variant in swords, being relatively rare in similarly shaped weapons, such as daggers.

Keywords: Hilt design with a double horseshoe arch, Peripheral notches for riveting, Arsenical copper, Natural gold alloy.

\footnotetext{
1. Centro de Arqueologia da Universidade de Lisboa (UNIARQ), Faculdade de Letras, Alameda da Universidade, 16oo-214 Lisboa, Portugal; ruigusmao@hotmail.com; mariananabais@gmail.com

2. Centro de Ciências e Tecnologias Nucleares ( $\left.\mathrm{C}_{2} \mathrm{TN}\right)$, Departamento de Engenharia e Ciências Nucleares, Instituto Superior Técnico, Universidade de Lisboa. Campus Tecnológico e Nuclear. Estrada Nacional 10 (km 139,7), 2695-o66 Bobadela LRS, Portugal; pvalerio@ctn.tecnico.ulisboa.pt; amsoares@ctn.tecnico.ulisboa.pt
}

3. Institute of Archaeology, University College London, 31-34 Gordon Square, Kings Cross, London WCiH oP, United Kingdom 


\section{INTRODUÇÃO}

A espada, objecto deste pequeno estudo que ora se publica, foi encontrada, há mais de 15 anos, durante a abertura de uma vala de drenagem junto ao Monte das Oliveiras, na margem esquerda do Guadiana, próximo da cidade de Serpa (Figura 1). Apresentava algumas pequenas torções e amolgadelas e quem a encontrou procurou endireitá-la, ao mesmo tempo que a "limpou", retirando-lhe os produtos de corrosão superficial. A espada tem-se mantido na posse do achador, residente em Safara, que durante a efectivação de uma exposição nessa aldeia, no ano passado, sobre as escavações arqueológicas realizadas no Castelo Velho de Safara, a mostrou a dois de nós (R.S. e M.N.). A espada foi encontrada a pouca profundidade, aparentemente descontextualizada, embora, segundo o achador, num moroiço, na vizinhança imediata da vala de drenagem, podia-se observar uma grande laje (de uma sepultura destruída?).

Nos arredores mais próximos do Monte das Oliveiras conhecem-se vários sítios arqueológicos, designadamente uma barragem romana, o Muro dos Mouros (Quintela et al., 1986), associada à villa romana da Cidade das Rosas (Caeiro, 1978, 1987), e, em frente desta, na outra margem do Barranco da Morgadinha, o sítio de fossas do Bronze Final do Sudoeste da Cidade das Rosas 4 (Baptista e Gomes, 2012), enquanto que, a menos de $1 \mathrm{~km}$ do Monte das Oliveiras, a noroeste, existe o recinto de fossos calcolítico da Folha do Ouro 1 (Valera et al., este volume).

As espadas pré-históricas, nomeadamente esta que pelo seu aspecto indicava que teria essa cronologia, são um tipo de arma rara no nosso território e, mesmo, em todo o sudoeste peninsular. No entanto, relativamente próximo, a cerca de $7 \mathrm{~km}$ do Monte das Oliveiras (ver Figura 1), foi encontrada a espada da Horta do Folgão, como dádiva funerária de um enterramento efectuado num hipogeu, atribuível ao Bronze Pleno do Sudoeste e datável da transição entre o $1^{\circ}$ e o $2^{\circ}$ quartel do II Milénio a.C. (Ponte et al., 2012).

\section{A ESPADA}

\subsection{Descrição sumária}

A espada do Monte das Oliveiras (MO), tal como se encontra actualmente, tem $45 \mathrm{~cm}$ de comprimento e cerca de $5 \mathrm{~cm}$ de largura máxima na zona de encabamento, a qual tem forma aproximadamente quadrangular (Figura 2). Apresenta um ligeiro estreita- mento a seguir à zona de encabamento e a lâmina, por seu lado, é uma folha triangular, plana, com afilamento nos gumes, encontrando-se fracturada na extremidade distal. Segundo o seu achador, essa fractura resultou do trabalho efectuado para a endireitar, tendo o pequeno fragmento sido perdido na oficina onde a operação se realizou. Esse fragmento teria cerca de $5 \mathrm{~cm}$ de comprimento e terminaria em ponta, pelo que a espada/estoque teria originalmente um comprimento de cerca de $50 \mathrm{~cm}$. O artefacto não apresenta, actualmente, qualquer patina, embora numa ou noutra zona surjam alguns laivos esverdeados, resquícios da patina primitiva que cobriria a peça.

O encabamento seria efectuado através de três rebites colocados em entalhes, dois laterais e um a meio na extremidade proximal. Conservam-se dois, um em cada entalhe lateral. Têm comprimentos máximos diferentes: $2,9 \mathrm{~cm}$ e 2,4 cm. Estamos em crer que um deles não estará na sua posição primitiva: o punho seria, com certeza, simétrico e por isso, logicamente, o rebite de maior comprimento não deveria estar num entalhe lateral, mas sim no entalhe mediano da zona de encabamento. Note-se que os rebites também não apresentam qualquer patina pelo que, aquando da limpeza da arma, estes deverão ter sido destacados da mesma, limpos e, por fim, colocados nos entalhes laterais, não correspondendo a sua posição actual à posição primitiva. $\mathrm{O}$ corpo cilíndrico dos rebites tem um diâmetro aproximado de $6 \mathrm{~mm}$, enquanto as extremidades dos mesmos apresentam a forma de calotes esféricas, com um diâmetro máximo de cerca de $11 \mathrm{~mm}$. As calotes esféricas encontram-se revestidas por uma folha de ouro, a qual terá sido fixada por pressão e brunimento, como é indiciado pelo seu aspecto e pelo o que se observa no reverso dessas calotes (Figura 3 ).

$\mathrm{Na}$ área de encabamento, numa das faces, apesar do "tratamento" que a espada sofreu a seguir à sua descoberta, pode observar-se a marca que o punho original, possivelmente de material perecível (madeira?), deixou - um duplo arco em ferradura, algo rebaixado (Figura 4) - cujo interesse e também importância serão sublinhados mais adiante.

\subsection{Composição elementar}

Uma vez que se desconhece o eventual contexto arqueológico, se porventura existia, a que MO estaria associada, era de importância primordial determinar as composições do metal/liga, quer da lâmina, 
quer da folha de ouro que cobre as extremidades dos rebites, composições essas que poderiam indiciar uma cronologia para esta arma. Assim, fazendo uso de um espectrómetro portátil Bruker Si Titan equipado com um tubo de raios $\mathrm{X}$ com ânodo de ródio, um detector SSD e um colimador de $5 \mathrm{~mm}$ para a análise de áreas de dimensão reduzida, foram efectuadas diversas análises nas faces opostas da lâmina e dos dois rebites. Os valores médios das diversas análises efectuadas encontram-se na Tabela 1.

Trata-se, por conseguinte, de uma espada manufacturada em cobre arsenical, enquanto que a folha de ouro que recobre os terminais dos rebites é feita de uma liga natural de ouro e prata, tendo em conta o seu teor de cobre $(<1 \%)$ (ver, por exemplo, Valério et al., 2017). A associação desta liga a um grande artefacto de cobre arsenical indicia uma antiguidade para esta técnica de douramento, para a qual ainda não existiam ligas artificiais de ouro e prata, como será discutido mais adiante.

\section{A ESPADA DO MONTE DAS OLIVEIRAS NO CONTEXTO DAS ARMAS DE BASE COBRE DA PENÍNSULA IBÉRICA}

A composição elementar de MO permite atribuir-lhe uma cronologia dentro do Bronze Pleno do Sudoeste, uma vez que as ligas de cobre arsenical são usuais durante este período (Valério et al., 2016), enquanto as de bronze são predominantes no Bronze Final (Valério et al., 2013, 2015) e os encabamentos de rebites não existem no Calcolítico, segundo Montero Ruiz et al. (2014), embora actualmente se conheçam alguns exemplos extremamente raros (ver, por exemplo, Blasco et al., 2019, Fig. 17b). Por outro lado, no sudoeste peninsular, as ligas de bronze surgem apenas na transição da primeira para a segunda metade do II Milénio (Valério et al., 2014) e se a espada fosse da segunda metade seria pouco provável que, tratando-se de um artefacto de prestígio, não fosse manufacturada nessa nova liga. Além disso, deverá ter-se em conta que a utilização de apenas três entalhes e ausência de furos para a fixação dos rebites é relativamente rara nos diversos tipos de encabamento de armas na Idade do Bronze, designadamente no que se refere aos punhais, encontrando-se completamente ausente, até hoje, nas espadas, constituindo MO caso único. A espada de Priego de Córdoba, em que o encabamento rebitado apresenta dois entalhes laterais e um orifício media- no na extremidade proximal (Hitos Urbano, 1991), será, porventura, a que mais se assemelha à do Monte das Oliveiras, embora o seu comprimento seja bastante menor $(39 \mathrm{~cm})$. A esta espada tem sido atribuída uma filiação argárica e, por conseguinte, uma cronologia do Bronze Pleno. Brandherm (2003), no estudo que efectuou sobre punhais, espadas e alabardas do Calcolítico e da Idade do Bronze da Península Ibérica, publica largas centenas de punhais e adagas que englobam apenas poucas dezenas destes artefactos com o mesmo tipo de encabamento de $\mathrm{MO}$, os quais na sua maior parte constituem o tipo $A B$ 19, que denominou de variante Periana (Tafel 69 e 70), com base nas características de um punhal (Tafel 70, no 1133) proveniente do sítio com esse nome, na província de Málaga. A solução técnica de encabamento correspondente a esta variante é, pois, relativamente rara no grande conjunto de punhais conhecidos e, segundo Brandherm (2003), datável do Bronze Pleno, da sua primeira metade (Tafel 195). No território da margem esquerda do Guadiana conhecem-se três punhais que apresentam este tipo de encabamento: o da cista do Carapetal (CRo1.o1), atribuível a um momento antigo dentro do Bronze Pleno do Sudoeste, dada a forma do vaso cerâmico que o acompanhava (Soares, 1976/77), tendo sido manufacturado em cobre arsenical (CRor: lâmina: Cu 98,9\%; As 1,1 \%; rebite: Cu 89,5\%; As 10,5\%) e os de Montinhos 6 (MT6.04711.18) e Torre Velha 12 (TV12.01011.01), pertencentes a espólios de enterramentos em hipogeu, que apresentam composições elementares muito similares à da espada MO (MT6: $\mathrm{Cu}$ 95, o \%; As 5,o \% e TV12: Cu 94,8; As 5,2\%) (Valério et al., 2016, Fig. 1 e Tab. 2). Várias datas de radiocarbono foram obtidas para diversos hipogeus de Montinho 6, permitindo atribuir uma cronologia do $2^{\circ}$ quartel do II Milénio a.C. para as respectivas manifestações funerárias, enquanto o enterramento do hipogeu de Torre Velha 12 também foi datado por radiocarbono, obtendo-se uma cronologia na transição do $2^{\circ}$ para o $3^{\circ}$ quartel (Valério et al., 2016, Tab. 1 e Fig. 2). Deverá notar-se que a espada da Horta do Folgão, já atrás referida, com um comprimento de cerca de $47 \mathrm{~cm}$ e uma composição elementar também semelhante à da MO (HF: Cu 95,7\%; As 4,3\%) difere desta última no encabamento. A da Horta do Folgão teria seis rebites, encontrando-se dois deles in situ preenchendo os respectivos orifícios circulares, enquanto os outros quatro, encontrados soltos, teriam sido colocados em quatro dos entalhes 
laterais (Ponte et al., 2012). Na área de encabamento pode observar-se ainda mais um entalhe, bem como dois orifícios circulares, que não teriam sido utilizados ou cujos rebites não foram encontrados. Contemporânea desta espada e muito semelhante a ela, quer na forma, quer na composição elementar, é a espada encontrada numa sepultura em La Mesa de Setefilla (Aubet Semmler, 1981; Aubet Semmler et al., 1983). Estas espadas, associadas a esqueletos humanos datados pelo radiocarbono na transição entre $\mathrm{o} 1^{\circ}$ e $2^{\circ}$ quartel do II Milénio a.C., seriam um pouco anteriores aos punhais de MT6 e TV12 atrás referidos, e indiciam, por conseguinte, que $\mathrm{MO}$ seria ligeiramente posterior a estas espadas.

Um dos atributos raros, até pela sua cronologia, da espada do Monte das Oliveiras é o douramento dos terminais dos rebites (Figura 3), o que sublinha o caracter excepcional desta arma. Embora se desconheça se o punho seria revestido a ouro, como acontece na célebre espada de Guadalajara (Almagro Gorbea, 1972; Brandherm, 1998), MO seria, com certeza, um artefacto de elevado prestígio. A técnica utilizada no douramento das cabeças dos rebites tem um paralelo estreito no douramento de uma tacha de bronze, certamente decorativa, encontrada em escavações arqueológicas realizadas no sítio do Bronze Final de Entre Águas 5 (Serpa), no qual existia uma oficina metalúrgica (Valério et al., 2013). Ao anverso da cabeça deste artefacto, ligeiramente cónica e larga, foi aplicada uma folha de ouro por um processo mecânico, muito provavelmente por pressão e brunimento sobre o anverso, enquanto a borda da folha foi dobrada sobre o reverso, a fim de obter uma boa adesão mecânica à sua base (Figura 5). A análise elementar da folha de ouro de Entre Águas 5 permitiu determinar que se trata de uma liga de $\mathrm{Au}-\mathrm{Ag}$, possivelmente artificial, com $11,6 \%$ de Ag e cerca de $1 \%$ de $\mathrm{Cu}$. Artefactos de ouro nativo, designadamente ligas de Au-Ag do Bronze Pleno do Sudoeste encontrados no sul de Portugal, designadamente no concelho de Serpa como, por exemplo, as cadeias de espirais de Vale de Viegas e o torques de Vila Nova de S. Bento têm percentagens de prata inferiores a $20 \%$, enquanto que o cobre aparece apenas como impureza (<1\%). Já as ligas ternárias de $\mathrm{Au}-\mathrm{Ag}-\mathrm{Cu}$ (com teores de $\mathrm{Cu}>1$ \%) surgem no Bronze Final do Sudoeste, constituindo bons exemplos as jóias da Herdade do Álamo (Sobral da Adiça, Moura) e da Herdade das Cortes (Alvito) (Armbruster e Parreira, 1993; Hartmann, 1982; Soares et al., 2004).
Por fim, também a impressão do duplo arco em ferradura, resultante do tipo de encabamento que a espada do Monte das Oliveiras sofreu, contribui para se considerar MO como um artefacto excepcional e raro. Na realidade, esta impressão de arco em ferradura duplo parece ser exclusiva das espadas (cerca de 20 exemplares - Gómez Ramos, 2001) e de raríssimos punhais (apenas três ou quatro; ver Brandherm, 2003, Tafels 49, no 802; 69, no 1113A; 70, no 1133 e no 1138) do Bronze Pleno da Península Ibérica. Na Península, as espadas com a impressão destes arcos duplos distribuem-se pela sua metade este, ocorrendo em três zonas: no sudeste (na área correspondente à Cultura de El Argar), no centro peninsular (região de Madrid, por exemplo) e no norte, na região cantábrica (ver Gómez Ramos, 2001, Fig. 3), encontrando-se ausentes em toda a área oeste com excepção da espada de bronze de Forcas (Orense), atribuível ao Bronze Final, e agora esta, a do Monte das Oliveiras. Também, os punhais com encabamento rebitado em três entalhes, tal como MO, parecem distribuir-se pelo sul e sudeste ibérico e os poucos exemplares no território português registam-se no sudoeste, designadamente na margem esquerda do Guadiana, como referido atrás. A exclusividade ibérica do tipo de encabamento que deixa a impressão em duplo arco em ferradura resultará, segundo diversos autores (ver, por exemplo, Almagro Gorbea, 1972, Gómez Ramos, 2001), duma origem argárica para o protótipo ou protótipos de todas estas armas. Também a espada do Monte das Oliveiras, bem como os punhais com três entalhes para o encabamento rebitado encontrados no concelho de Serpa, apontam para uma difusão desta tipologia de armas a partir do sudeste ibérico. Note-se, por exemplo, que o punhal TV12.01011.01, de tamanho muito pequeno, tem paralelos estreitos, pelas suas dimensões, em muitos destes artefactos registados em sepulturas de $\mathrm{El} \mathrm{Ar-}$ gar, designadamente na sepultura 275 , onde um pequeno punhal com 3 entalhes rebitados foi encontrado (Schubart e Ulreich, 1991, p. 94 e Tafel 19, 275). De igual modo, as dádivas de sepultura do hipogeu de Belmeque (Soares, 1994; Soares et al., 1996) e de alguns dos hipogeus de Torre Velha 3 (Alves et al., 2010) apontam para uma influência nessa direcção.

\section{CONSIDERAÇÕES FINAIS}

A espada do Monte das Oliveiras, até pela utilização de ouro na sua manufactura, foi certamente um item 
de prestígio e o seu possuidor deveria ter um elevado status social. Embora tenha sido encontrada descontextualizada, as composições elementares, quer do corpo da espada (cobre arsenical), quer da folha de ouro (liga natural de $\mathrm{Au}-\mathrm{Ag}$ ) que cobria os terminais dos rebites que a fixavam ao punho, quer ainda dos paralelos conhecidos, incluindo punhais com a mesma tipologia e composição elementar, permitem datá-la da $1^{1}$ metade ou até, arriscando ser mais preciso, do $2^{\circ}$ quartel do II Milénio a.C. O arco duplo em ferradura que ficou impresso na área de encabamento resultante do design do punho em material perecível, tornam-na no primeiro exemplar com esta tipologia encontrado em território português, estendendo para oeste da Península Ibérica a dispersão destas armas, com esta cronologia. Por outro lado, deverá notar-se que a técnica de douramento utilizada nos rebites da espada do Monte das Oliveiras tornam-na no exemplar de aplicação desta técnica mais antigo até hoje registado na Península Ibérica.

\section{AGRADECIMENTOS}

O nosso muito obrigado ao Senhor Joaquim Manuel Batarda Isqueiro, a pessoa que encontrou a espada e a tem preservado até hoje, e que muito amavelmente a disponibilizou em sua casa para procedermos ao seu estudo. A caracterização arqueometalúrgica foi efectuada no âmbito do Projecto UID/ Multi/04349/2019 financiado pela Fundação para a Ciência e a Tecnologia.

\section{REFERÊNCIAS BIBLIOGRÁFICAS}

ALMAGRO GORBEA, M. (1972) - La espada de Guadalajara y sus paralelos peninsulares. Trabajos de Prehistoria. 29, pp. $55-82$.

ALVES, C., COSTEIRA, C.; ESTRELA, S.; PORFÍRIO, E.; SERRA, M.; SOARES, A.M.M. e MORENO-GARCÍA, M. (2010) - Hipogeus funerários do Bronze Pleno da Torre Velha 3 (Serpa, Portugal). O Sudeste no Sudoeste?! Zephyrus. 66, pp. 133-153.

ARMBRUSTER, B. e PARREIRA, R. (Coords.) (1993) - Inventário do Museu Nacional de Arqueologia. Colecção de Ourivesaria. Do Calcolítico à Idade do Bronze. Vol. I. Lisboa: Instituto Português de Museus.

AUBET SEMMLER, M. E. (1981) - Sepulturas de la Edad del Bronce en La Mesa de Setefilla (Sevilla). Madrider Mitteilungen. 22, pp. 127-149.
AUBET SEMMLER, M.E.; SERNA, M. R.; ESCACENA, J.L. e RUIZ DELGADO, M. M. (1983) - La Mesa de Setefilla, Lora del Rio (Sevilla). Campaña de 1979. Excavaciones Arqueologicas en España. Madrid: Ministerio de Cultura.

BAPTISTA, L. e GOMES, S. (2012) - Cidade das Rosas 4 (S. Salvador, Serpa): breve notícia sobre os fragmentos cerâmicos com ornatos brunidos. Actas do VEncontro de Arqueologia do Sudoeste Peninsular (Almodôvar, 2010). pp. 605-614.

BLASCO, C.; LIESAU, C. e RÍOS, P. (2019) - El registro funerario campaniforme de la Región de Madrid, reflejo de una sociedad plural y compleja. In Un brindis por el príncipe! El vaso campaniforme en el interior de la Península Ibérica. Vol. I, pp. 247-277.

BRANDHERM, D. (1998) - Algunas consideraciones acerca de la espada de Guadalajara. Un excepcional depósito desarticulado del Bronce Medio de la Meseta? Trabajos de Prehistoria. 55(2), pp. 177-184.

BRANDHERM, D. (2003) - Die Dolche und Stabdolche der Steinkupfer und Iteren Bronzezeit auf der Iberischen Halbinsel. Frank Steiner Verlag, Stuttgart.

CAEIRO, J.O.S. (1978) - Observações sobre a cerâmica comum romana do século III proveniente da Cidade das Rosas, Serpa. Actas das III Jornadas Arqueológicas. Lisboa: Associação dos Arqueólogos Portugueses. Vol. 1, pp. 251-271.

CAEIRO, J.O.S. (1987) - A Cidade das Rosas. Arquivo de Beja. 2- Série, 4, pp. 111-125.

HARTMANN, A. (1982) - Prähistorische Goldfunde aus Europa. Studien zu den Anfängen der Metallurgie. 3:2. Berlin: Mann.

HITOS URBANO, M.A. (1991) - Espada inédita de la Edad del Bronce hallada en el término municipal de Priego de Córdoba. Antiquitas. 2, pp. 42-46.

MONTERO RUIZ, I.; LUGO ENRICH, L.B.; ÁLVAREZ GARCÍA, H.J.; GUTIÉRREZ-NEIRA, P.C.; MURILLO-BARROSO, M.; PALOMARES ZUMAJO, N.; MENCHÉN HERREROS, G.; MORALEDA SIERRA, J. e SALAZER-GARCÍA, D.C. (2014) - Copper for Dead. Archaeometric Study of Metal Objects from the Prehistoric Megalithic Monument Castillejo del Bonete (Terrinches, Ciudad Real). Zephyrus.73, pp.109-132.

PONTE, T.R.N.; SOARES, A.M.M.; ARAÚJO, M.F.; FRADE, J.C.; RIBEIRO, I.; RODRIGUES, Z.; SILVA, R.J.C. e VALÉRIO, P. (2012) - O Bronze Pleno do Sudoeste da Horta do Folgão (Serpa, Portugal). Os Hipogeus Funerários. O Arqueólogo Português. Série V, 2, pp. 265-295.

QUINTELA, A.C.; MASCARENHAS, J.M. e CARDOSO, J.L.S.C. (1986) - Barragens romanas do distrito de Beja. Actas do $1^{\circ}$ Encontro de Arqueologia da Região de Beja, (Beja, 17 1819 Janeiro 1986). Arquivo de Beja. 2aㅡ Série, 3, pp. 153-165. 
SCHUBART, H. e ULREICH, H. (1991) - Die Funde der Südostspanischen Bronzezeit aus der Sammlung Siret. Philipp von Zabern, Mainz.

SOARES, A.M.M. (1976/77) - Uma cista do Bronze do Sudoeste em Aldeia Nova de São Bento (Serpa). Setúbal Arqueológica. 2/3, pp. 273-279.

SOARES, A.M.M. (1994) - O Bronze do Sudoeste na Margem Esquerda do Guadiana. As Necrópoles do Concelho de Serpa. Actas das V Jornadas Arqueológicas. Lisboa, vol. II, pp. 179-197.

SOARES, A.M.M.; ARAÚJO, M.F. e ALVES, L.C. (2004) Análise química não-destrutiva de artefactos em ouro pré e proto-históricos: alguns exemplos. Revista Portuguesa de Arqueologia.7(2), pp. 125-138.

SOARES, A.M.M.; ARAÚJO, M.F.; ALVES, L. e FERRAZ, M.T. (1996) - Vestígios Metalúrgicos em Contextos do Calcolítico e da Idade do Bronze no Sul de Portugal. Miscellanea em Homenagem ao Professor Bairrão Oleiro. Edições Colibri, Lisboa, pp. 553-579.

VALERA, A.; PEREIRO, T. do; VALÉRIO, P. e SOARES, A.M.M. (este volume) - O recinto da Folha do Ouro 1 (Serpa) no contexto dos recintos de fossos calcolíticos alentejanos.

VALÉRIO, P.; SILVA, R.J.; SOARES, A.M.M.; ARAÚJO, M.F.; GONÇALVES, A.P. e SOARES, R.M. (2015) - Combining X-ray based methods to study the protohistoric bronze technology in Western Iberia. Nuclear Instruments and Methods in Physics Research B. 358, pp. 117-123.

VALÉRIO, P.; SOARES, A.M.M.; ARAÚJO, M.F. e CARVALHO, A.F. (2017) - Micro-EDXRF investigation of Chalcolithic gold ornaments from Portuguese Estremadura. X-Ray Spectrometry. 46, pp. 252-258.

VALÉRIO, P.; SOARES, A.M.M.; ARAÚJO, M.F.; SILVA, R.J. e BAPTISTA, L. (2016) - Middle Bronze Age arsenical copper alloys in Southern Portugal. Archaeometry. 58(6), pp. 1003-1023.

VALÉRIO, P.; SOARES, A.M.M.; ARAÚJO, M.F.; SILVA, R.J.; PORFÍRIO, E. e SERRA, M. (2014) - Arsenical copper and bronze in Middle Bronze Age burial sites of southern Portugal: the first bronzes in Southwestern Iberia. Journal of Archaeological Science. 42, pp. 68-8o.

VALÉRIO, P.; SOARES, A.M.M.; SILVA, R.J.; ARAÚJO, M.F.; REBELO, P.; NETO, N.; SANTOS, R. e FONTES, T. (2013) - Bronze production in Southwestern Iberian Peninsula: the Late Bronze Age metallurgical workshop from Entre Águas 5 (Portugal). Journal of Archaeological Science. 40, pp. 439-451. 


\begin{tabular}{llll}
\hline & $\mathrm{Cu}(\%)$ & $\mathrm{As}(\%)$ & \\
Lâmina & 94,4 & 5,5 & $\mathrm{Cu}(\%)$ \\
\hline Folha de Ouro & $\mathrm{Au}(\%)$ & $\mathrm{Ag}(\%)$ & \\
Rebite 1 & & & 0,30 \\
Rebite 2 & 89,6 & 10,1 & 0,37 \\
\hline
\end{tabular}

Tabela 1 - Análise por p-EDXRF dos elementos constituintes da espada do Monte das Oliveiras.

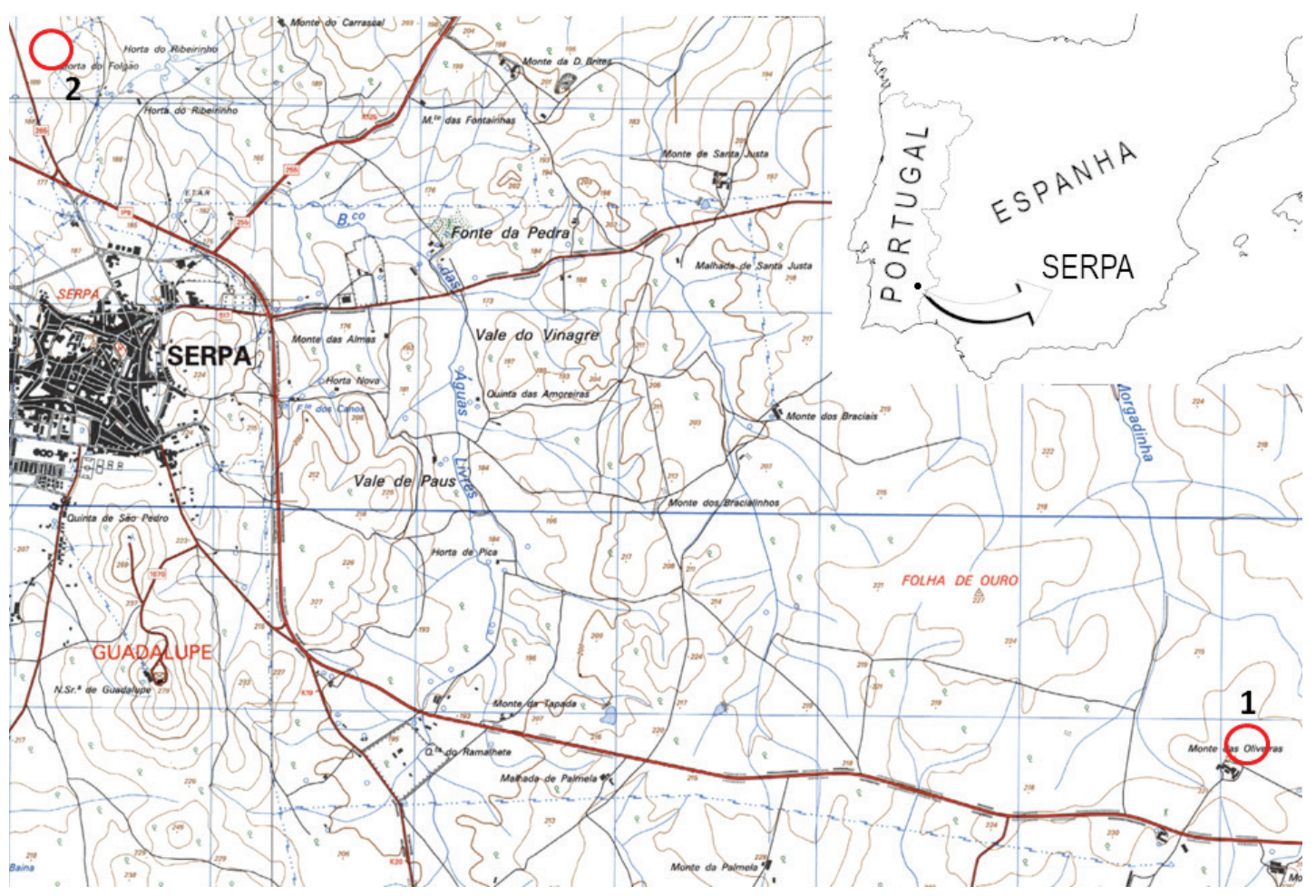

Figura 1 - Localização dos sítios Monte das Oliveiras (1) e Horta do Folgão (2) na Península Ibérica e na C.M.P., 1:250oo, fls. 522, 523, 532 e 533 . 


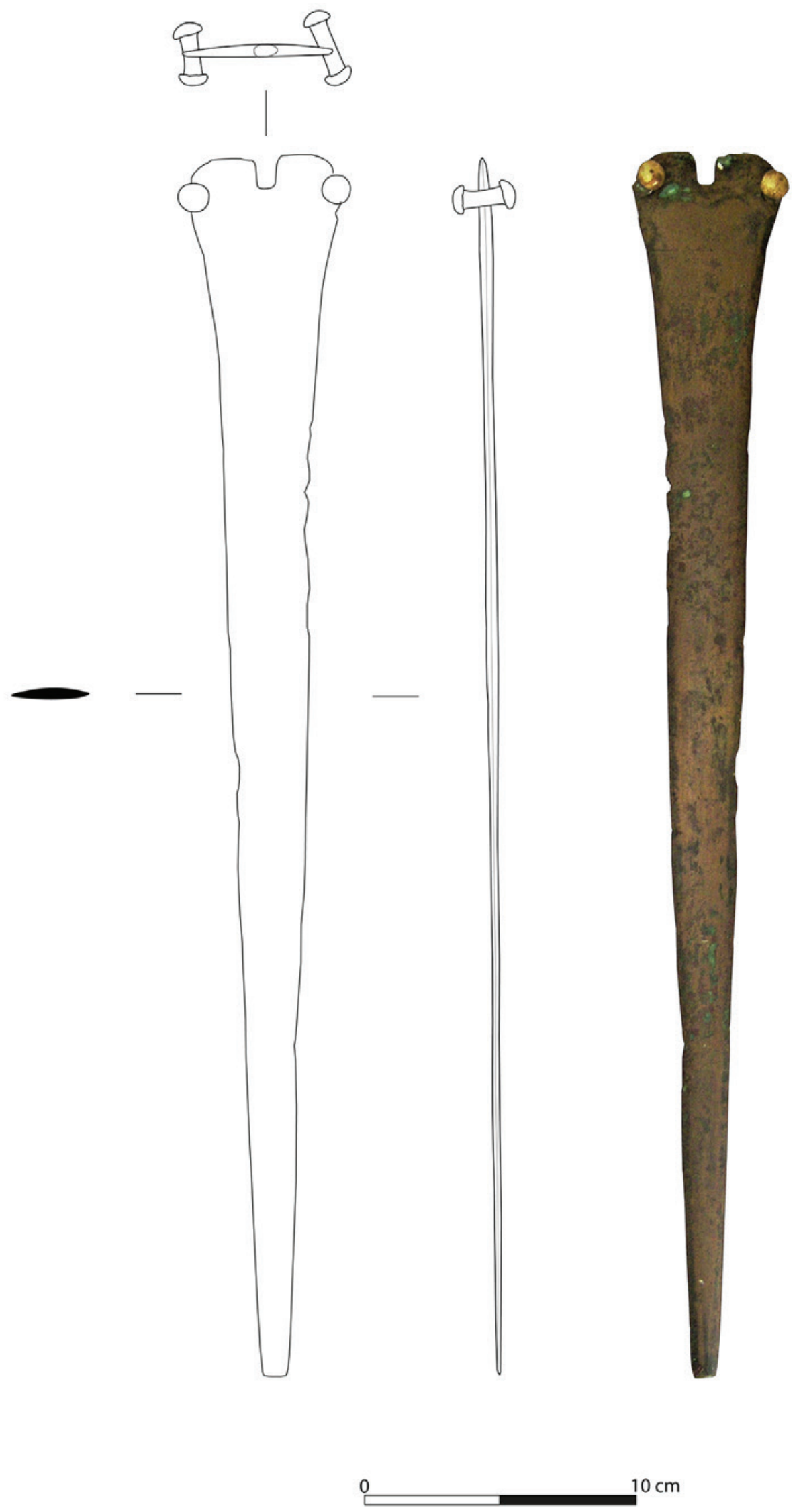

Figura 2 - A espada do Monte das Oliveiras. 

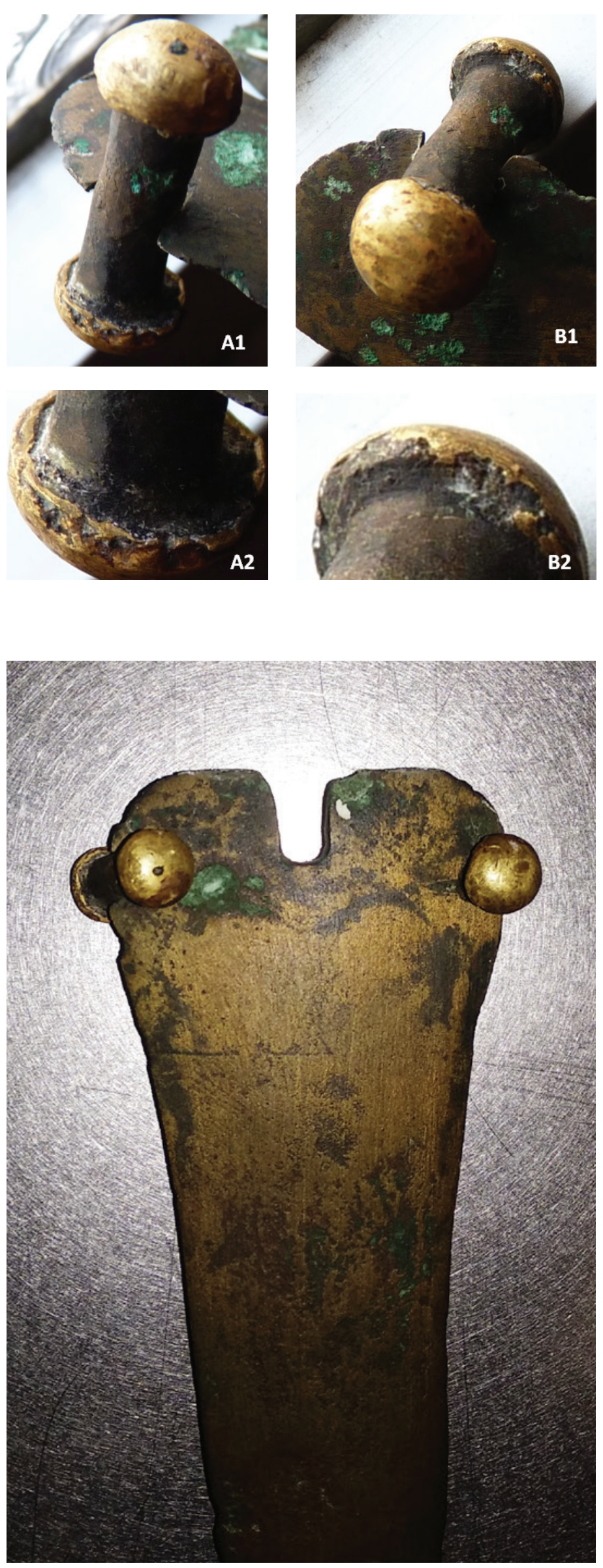

Figura 3 - Os dois rebites conservados da espada do Monte das Oliveiras com o anverso das cabeças coberto por uma folha de ouro. Notem-se as dobras das folhas de ouro no reverso das calotes esféricas, indiciando a técnica utilizada no douramento.
Figura 4-A zona de encabamento da espada do Monte das Oliveiras observando-se a impressão dos dois arcos em ferradura. 

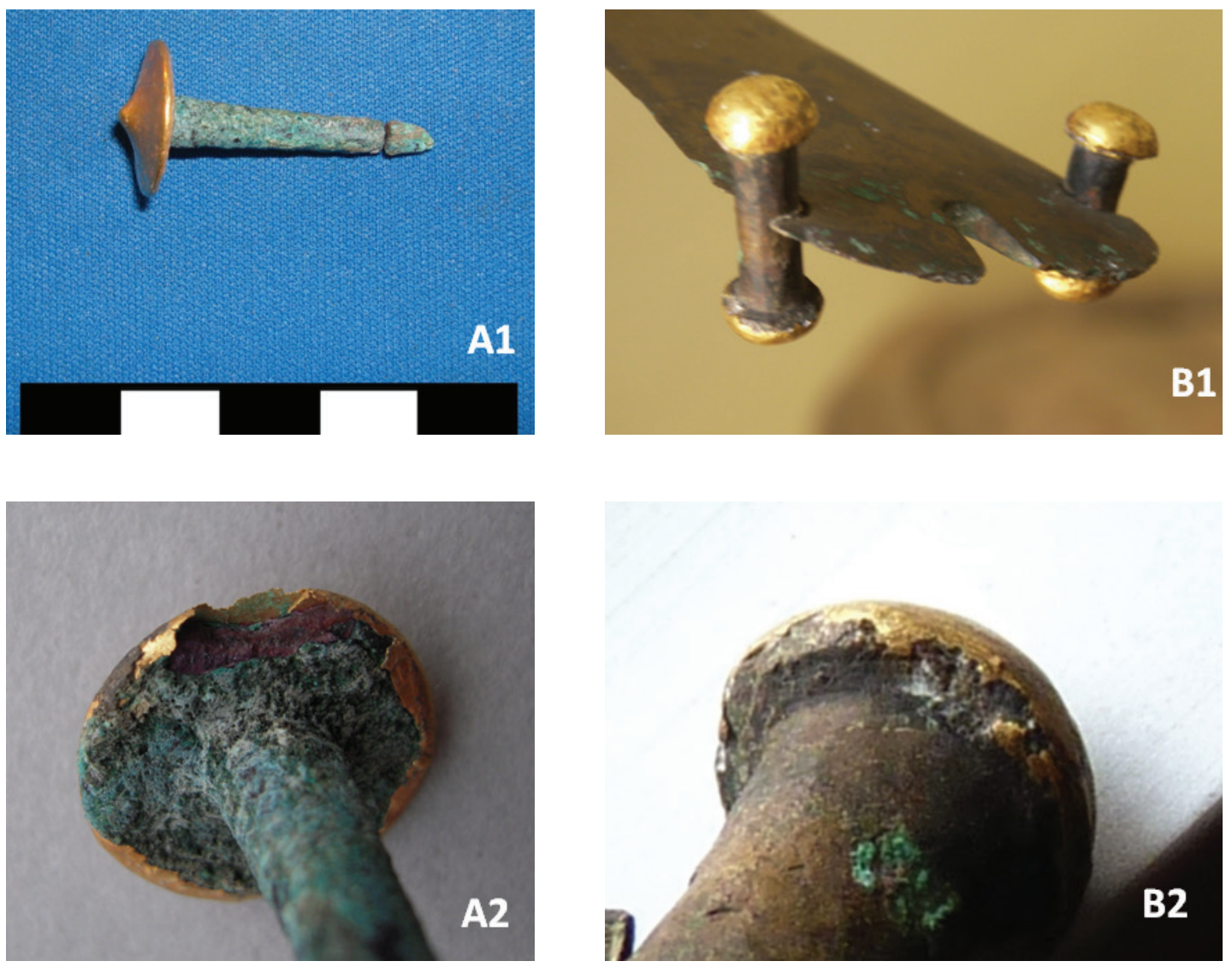

Figura 5 - Comparação entre a tacha de bronze de Entre Águas 5 (A), datável do Bronze Final, e os rebites de cobre arsenical da espada do Bronze Pleno do Monte das Oliveiras (B), todos eles revestidos a folha de ouro utilizando a mesma técnica de douramento. 



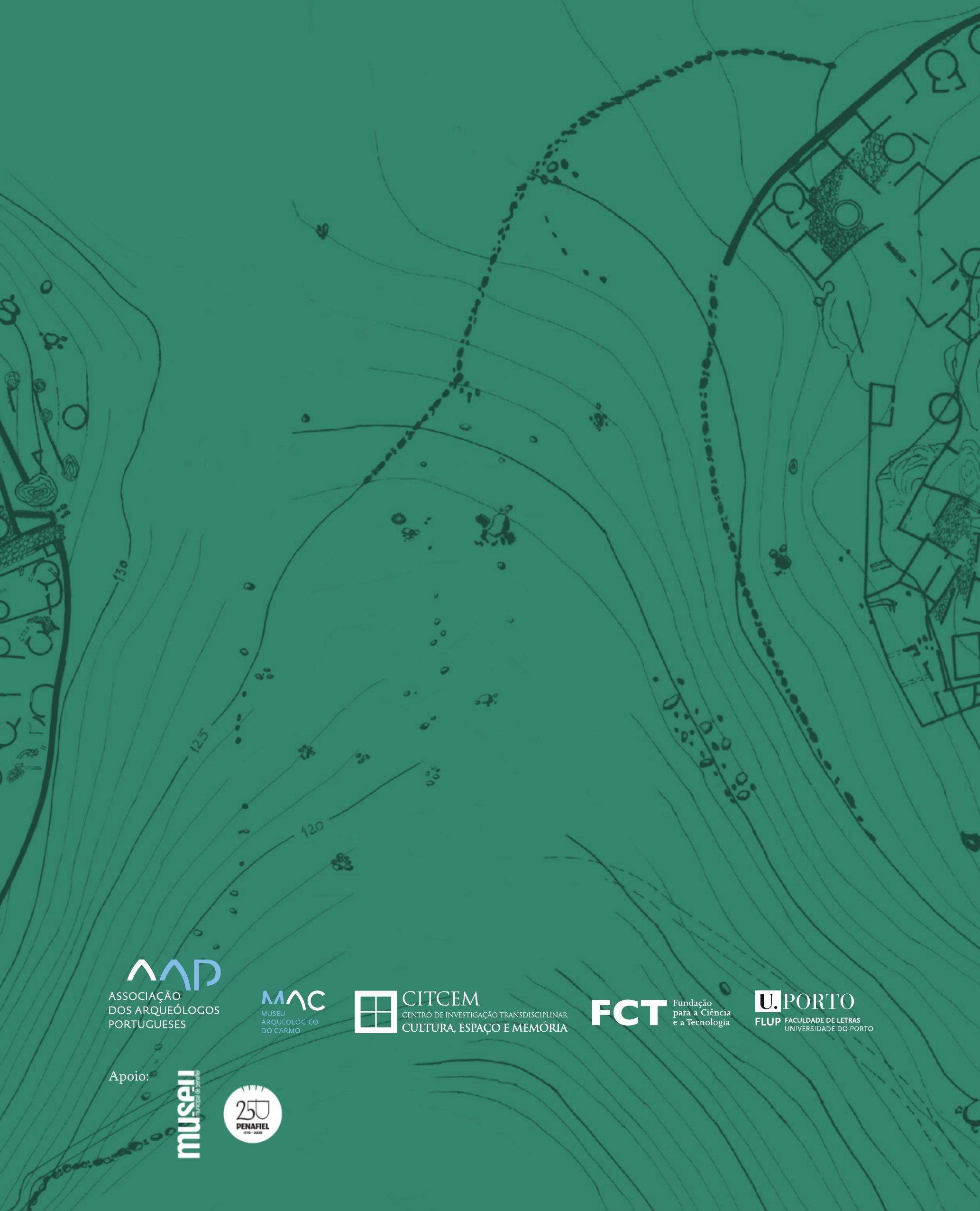

